\title{
Student Analysis Of Differences Perceptions On Professionalism Of Lecturer In Palembang
}

\author{
Delta Khairunnisa, Indri Ariyanti, Nita Novita, M. Aris Ganiardi \\ Informatic Management \\ State Polytechnic of Sriwijaya, Palembang, Indonesia \\ Email: delta.khairunnisa@gmail.com
}

\begin{abstract}
The research entitled Student Analysis of Differences Perceptions on Professionalism of Lecturer in Palembang. The purpose of this research is to know the perception of student to professionalism of lecturer in vocational and academic education. Data collection was done by distributing questionnaires using 5 Likert scales. Sampling using purposive sampling. Analytical technique used is Structural Equation Model (SEM). The results obtained in this study is there are significant student perception to professionalism of the lecturers, in terms of knowledge, skill and personality. The implication of this research is to be effective, lecturers need a combination of professional knowledge and specialized skills as well as their own personal qualities and experiences.
\end{abstract}

Keywords : Perception, Profesionalism, Vocational, Academic.

\section{INTRODUCTION}

The National Education System divides educational programs in higher education into academic education (undergraduate, master, and doctorate), professional / specialist education and vocational education (diploma). Academic education focuses on the mastery and development of certain disciplines of science, technology, and art. While vocational education is focused on the mastery of certain applied skills. The existing universities in Palembang city when viewed from academic education can include such as Sriwijaya University, Palembang University, Bina Dharma University, Muhammadiyah University, IBA University, Tridinanti University, Sjakhyakirti University and so on. While vocational education includes Sriwijaya State Polytechnic, Health Polytechnic, Anika Polytechnic, Akamigas Polytechnic, Darussalam Polytechnic and so on.

The role of Higher Education is to carry out education, in addition to research and community service. Education conducted by universities through the learning process. In the learning process there are learning activities. Learning is a form of growth or change in a person expressed in new ways or patterns of behavior. Learning is an active undertaking of one's self made to change his own behavior (Wibowo, 2014). In the learning process required a learning strategy, namely in the form of activities undertaken between lecturers with students for the purpose of learning can be achieved effectively and efficiently. Active learning is an instructionalmethod in which students become engaged participants in the classroomthrough the use of in-class written exercises, games, problem sets, audienceresponse systems, debates, class discussions, etc (Miller and Metz, 2014). Conceptions of learning are commonly found to fall into two main categories: learning as information

Jurnal Manajemen/Volume XXIII, No. 03, October 2019: 427-443

DOI: http://dx.doi.org/10.24912/jm.v23i3.579 
transmission and learning as supporting students.In learning we build on the learner's prior knowledge and models of understanding irrespective of whether these are formally 'correct' or 'incorrect'(Ramadhan and Soenarto, 2015).The direct transmission view of student learning implies that the role of lecturers is to transfer knowledge in a clear and structured way, to explain the correct solutions to give students clear and resolve problems, and to ensure calm and concentration in the classroom (Mofreh et.all, 2013). The interaction between lecturers and students in the learning process shows that the relationship between them is so close. A good lecturer will build a deep closeness to their students and do not consider students as objects of learning but rather consider them as friends to share (Rahman, 2017). The role of lecturers is a facilitator who directs or guides students to achieve learning objectives. As a facilitator, lecturers should look for various ways to improve student success. A good lecturer has expertise in his field, so that it can direct or guide students. A lecturer is absolutely absolute requires sufficient professionalism because of a demand that if the lecturer is not professional then it will produce students who are also not professional. Lecturers in accordance with the field of science can provide knowledge to students according to their field of science. Lecturers who have certain skills can be placed according to their field of expertise so that the desired learning objectives can be achieved.

When asked to define professionalism, the definition would probably include examples of what is commonly considered professional-like behaviors (Creasy, 2015). In teacher education literature, most of these definitions agree that a professional demonstrates behaviors which potray the knowledge, skill and character of profession (Nurchayati, 2012). Teacher professionalism as a set of collectively held norms that regulate the teaching profession according to values and practices that are embedded in the experience of shared professional goals and relationships. Similarly, teacher professionalism is described as comprising the focus on teachers' work; becoming professional in one's outlook, knowledgeable and committed; developing professional judgment, professional ethics and ethos that pervades schools; and teacher identity (Komba et all., 2013). Professionalism is a quality that every good professional holder should have. Professionalism puts pressure on the quality that every person who wants to become professional be fulfilled. Lecturers who have professionalism will be a professional person. Professional commitment is also interpreted as the level where individuals can adopt the characteristics and perspectives of the profession. Commitment to profession refers to the characteristics of the profession that include working to achieve the best results by using the knowledge and skills one possesses (Susanto, 2019). Assessment of the professionalism of lecturers is done by the students because in the learning process there is an interaction between lecturers and students. While perception is a process that is the activity of sensing, organizing, and interpreting and providing an assessment of a particular object (Kotler, 2018). Students are the status that is held by a person because of their relationship with the college which is expected to become intellectual candidates. Students perceptions of lecturer professionalism are assessing lecturer knowledge, lecturer skill, and lecturer attitude / ethics / value (Linjee and Homkaew, 2016). Students perceptions of professionalism of lecturers are differentiated according to the scope of education provided, namely vocational education and academic

Jurnal Manajemen/Volume XXIII, No. 03, October 2019: 427-443

DOI: http://dx.doi.org/10.24912/jm.v23i3.579 
education. This difference of perception to assess whether a lecturer in performing its role in accordance with his / her skill / expertise.

Based on the background of the problems in this study is how the perception of students on the professionalism of lecturers in the Higher Education Environment Vocacional and Academic of Palembang City, is there positive relationship relationship between knowledge, skills, and personality toward an lecture professionalism ?

This research is done to know the perception of student to professionalism of lecturer, and to know whether there is a positive relationship between knowledge, skills, and personality toward an lecture professionalism in Higher Education Environment Vocacional and Academic of Palembang.

\section{THEORETICAL REVIEW}

Perception. Definition of perception according to (Agustin, 2018) is: Perception is a response (acceptance) directly from an uptake or is the process someone knows some things through his the five senses. Meanwhile, according to (Wibowo, 2014) perception is a process of observing and selecting, organizing and interpreting environmental stimulus. Perception by (Kotler, 2018), is perception is an individual process of choosing, organizing, and interpreting information inputs to create a meaningful picture of the world. Kotler also agrees with other experts that perception is limited by a selective process so that a person can have a different perception of the object. Based on some of these definitions can be concluded perception is a process that is the activity of sensing, organizing, and interpreting and provide an assessment of a particular object.

Perceptual inputs are first received, then process by the perceiver and resultant output becomes the base of behaviour. Behaviour is dependent on these perceived ouputs. The perception behaviour, inturnt, generates responses from the perceived and these reponses rise to a new set of inputs (Zakiyah and Nurwidawati, 2017).

Professionalism. Viewed in the (Agustin, 2018) professionalism is the quality, quality, and behavior that is the hallmark of a profession or a professional person. Professionalism is a quality that every good professional holder should have (Ramadhan and Soenarto, 2015). The definition gives a stress on the quality that must be met by everyone who wants to be professional. Quality in the above definition is established by professional organizations and must be obeyed by every member of the profession, in order to have a uniformity in terms of quality of services produced profession and to gain public confidence in the quality of services submitted by the profession. Referring to international standards, one's professionalism includes knowledge, skills, attitudes, ethics and values (Linjee and Homkaew, 2016).

Professionalism is determined as the competences that meet professional education standards so that a lecturer is required to possess a qualified professional background and to obtain the consequences as professionalization principles. These competences include of (1) pedagogical competence, (2) personal competence, (3) social competence, and (4) professional competence. Lecturer competences are related to how good lecturers fulfill their roles as an educator, including how well prepared lecturers in the class is until the

Jurnal Manajemen/Volume XXIII, No. 03, October 2019: 427-443

DOI: http://dx.doi.org/10.24912/im.v23i3.579 
evaluation needs to be done, how much the credits lecturers need to handle, and how long the process will last properly (Wardoyo et all., 2017).

Students. According to (Agustin, 2018), students are people who study in college. Students are the status that is held by a person because of their relationship with the college which is expected to become intellectual candidates.

Lecturer. According to (Kemenkeu, 2005), lecturers are professional educators and scientists with the primary task of transforming, developing and disseminating science, technology and the arts through education, research, and community service. The position of the lecturer as professional staff as referred to in Article 3 paragraph (1) in RI Law No.4/2005 (Kemenkeu, 2005) serves to improve the dignity and role of lecturers as learning agents, developers of science, technology, and art, as well as service to the community functioning improve the quality of national education.

Based on Article 7 paragraph (1) in RI Law No. 14/2005 (Kemenkeu,2005) the teaching profession and the teaching profession are special fields of work carried out based on the following principles: (1) having talents, interests, vocation, and idealism; (2) has a commitment to improve the quality of education, faith, piety, and noble character; (3) having academic qualifications and educational background in accordance with the task area; (4) having the required competencies in accordance with the task area; (5) has responsibility for carrying out professional duties; (6) earning income determined in accordance with work performance; (7) have the opportunity to develop professionalism on an ongoing basis with lifelong learning; (8) has a guarantee of legal protection in carrying out professional duties; and (9) has a professional organization that has the authority to regulate matters related to the task of teacher professionalism.

Lecture is a teaching method where an instructor is the central focus of information transfer. Typically, aninstructor will stand before a class and present information for the students to learn. Sometimes, they willwrite on a board or use an overhead projector to provide visuals for students. Students are expected to takenotes while listening to the lecture. Usually, very little exchange occurs between the instructor and thestudents during a lecture. This didactic method as education through thetransmission of information and suggests that this theory of learning assumes that students are passiverecipients of knowledge transmitted by the lecturer (Marmah, 2014).

Definition of Vocational Education and Academic Education. Based on RI Law No. 20/2003 (Ristekdikti, 2003) on National Education System, education programs in higher education include academic education (bachelor, master and doctorate), professional / specialist education and vocational education (diploma).In this study will be compared between vocational education with academic education. The difference between the two is as follows:

Vocational education is a system of higher education directed at the mastery of particular applied skills. Vocational education includes diploma I (D1), diploma II (D2), diploma III (D3) and diploma IV (D4) diploma programs. Graduates of vocational education get vocational degrees, such as A.Ma (Ahmad Madya), A.Md (Masters Expert)

Jurnal Manajemen/Volume XXIII, No. 03, October 2019: 427-443

DOI: http://dx.doi.org/10.24912/im.v23i3.579 
Academic education is a system of higher education directed at the mastery and development of certain disciplines of science, technology, and art. Academic education includes undergraduate (S1), master or master (S2) and doctoral (S3) education programs.

\section{METHODOLOGY}

Research Sites. The location of the research was conducted in the Higher Education Environment of Palembang City, which is a university that organizes vocational education and academic education. The location for vocational education is Sriwijaya State Polytechnic, while the location of academic education is Sriwijaya University.

Research Design. The study design includes population and sample of student data obtained by the researcher.Population is the whole group of people, events, or something that researchers want to investigate consists of objects and subjects that have certain characteristic qualities set by the researchers to be studied and then drawn conclusions (Sugiyono, 2018). The population of this study are students in the Higher Education Environment of Palembang City, namely Sriwijaya State Polytechnic and Sriwijaya University. According to (Sugiyono, 2018) provide suggestions on the sample size for the study as follows: The appropriate sample size in the study is between 30-500 samples. The formula for calculating sample size according to Slovin:

$\mathrm{n}=\mathrm{N}$

$1+\mathrm{N}(\mathrm{e})^{2}$

Where

$\mathrm{n}=$ number of samples

$\mathrm{N}=$ total population

$\mathrm{e}=$ error term, percent laxity inaccuracy due to sampling error that can still be tolerated (used 10\%)

The sample is expected to represent the respondent. The sample is determined using non probabilistic sampling, ie every element in the population does not have the same probability to be selected to be a sample or the selection of sample members is not random and objective (Subagyo, 2004). Non-probability sampling technique used in this research is purposive sampling, that is choosing the sample member which is adjusted to the purpose of research (Supomo and Indriantoro, 2002). The sample in this research are students at State Polytechnic of Sriwijaya and Sriwijaya University

Jurnal Manajemen/Volume XXIII, No. 03, October 2019: 427-443

DOI: http://dx.doi.org/10.24912/jm.v23i3.579 
Table 1. Population and sample

\begin{tabular}{c|c|c|c}
\hline No & University's name & $\begin{array}{c}\text { Students } \\
\text { (Population) }\end{array}$ & $\begin{array}{c}\text { sample (based on } \\
\text { Slovi's Formula) }\end{array}$ \\
\hline 1 & Sriwijaya University & 30.905 Students & 100 Students \\
\hline 2 & StatePolytechnic of Sriwijaya & 3.881 Students & 100 Students \\
\hline 3 & Total & 34.786 Students & 200 Students \\
\hline
\end{tabular}

Source : (Biro Pusat Statistik, 2015)

The university is a college consisting of a number of faculties that conduct academic and / or professional education in a number of specific disciplines. The sample consisted of several faculties and departments within Sriwijaya University, with active student status from semester 1 to final semester.

Polytechnic is a college that conducts applied education in a number of specialized knowledge areas. Samples taken consist of several majors and courses in the environment Sriwijaya State Polytechnic, with the status of students who are still active from semester 1 until the final semester.

Figure 1. Research Model

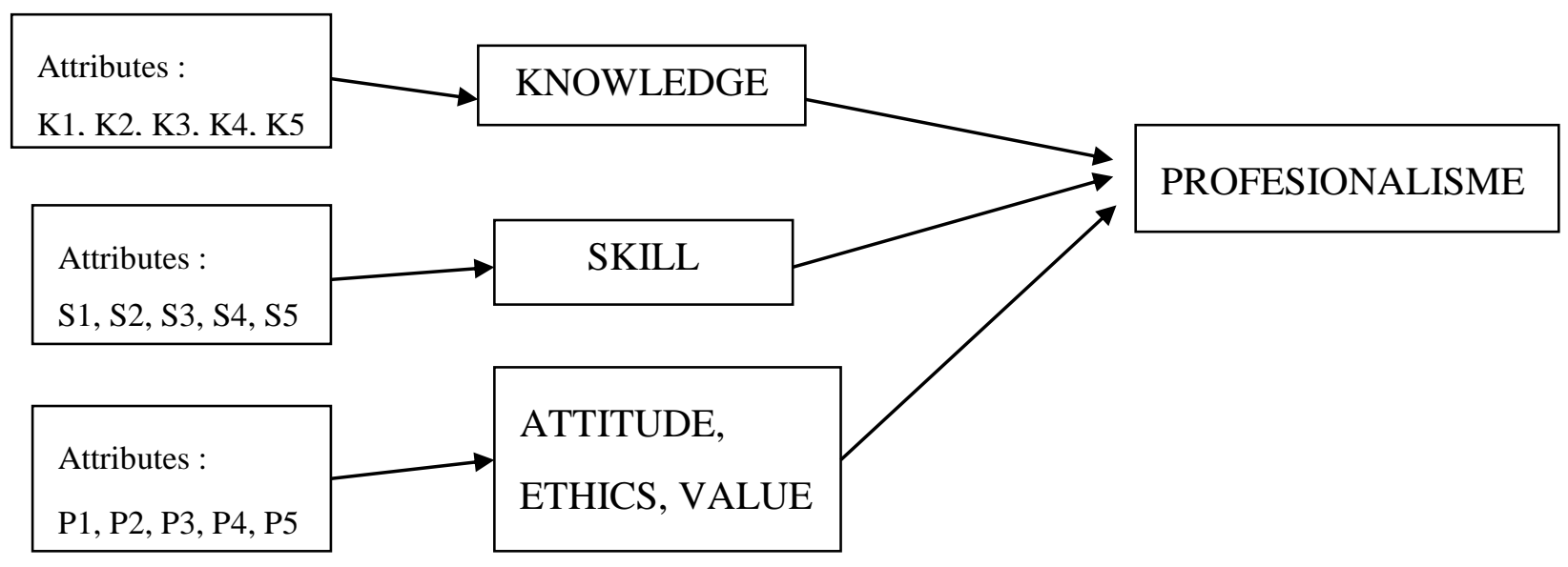

(Linjee and Homkaew, 2016)

The element of professional lecturer consist of knowledge of technical and special issues, law and constitution, environment, social, economy and culture. Skilss, namely tecnical skills, communication, interpersonal skills, quality consciousness, organization, business, management and leadhership. And attitude, including ethics. morals, integrity, responsibility and accountability (Susanto, 2018)

Knowledge (Knowledge ability), is knowledge possessed by a lecturer. As a professional, lecturers are required to have a number of competencies in order to perform their duties properly. The competence of the field of study namely the mastery of the discipline. The mastery of the discipline is concerned with the substance and methodology of knowledge (Hidayati and Siswati, 2017) 
Skill (skill ability), that is expertise or skill possessed by a lecturer.A good lecture is an art, akin to a stage performance in which the lecturer is the protagonist and holds the audience's attention to the end. Some of the skills involved in giving a good lecture stem from the lecturer's personality, but others can undoubtedly be practiced and learnt. While some lectures can be delivered as stand-alone teaching events, in most situations they form part of a course, which means that good lecturers must also understand the broader theories of good teaching (Rahman, 2017).

Attitude, Ethics, Value (personality ability), that personality owned by a lecturer.Attitudes express how people feel about something and are part of an individual's personality traits. A professional attitude is valuable in many ways, and knowing about these attitudes can also be very useful. People's attitudes towards their profession have an effect on their performance (Pamukkale, 2012).

Data Collection and Data Analysis Techniques. The data collected are primary and secondary data. Primary data is research data obtained directly from original source (not through intermediate media) (Supomo and Indriantoro, 2002). Primary data was obtained through questionnaires. Questionnaire is a data collection technique that is done by giving a set of questions or statements written to the respondent for the answer (Sugiyono, 2018). Questionnaires are designed with closed question models. The scale used in the question is 5 Likert scale, ie strongly agree (score 5), agree (score 4), neutral (score 3), disagree (score 2), strongly disagree (score 1). (Umar, 1999). According (Priyatno, 2014) testing the research instrument (questionnaire) is valid and reliable performed the following tests:

Validity. Validity test is done by making limits on the variables to be measured. Then determine the dominant factor of the preparation of the questionnaire. The next questionnaire will be tested with related factors. Then tested whether valid or not. Invalid will be removed or corrected.

Reliability. Reliability test is used to measure the consistency of research instruments. It is said to be reliable if the gauge shows consistent results.

While secondary data is indirect research data through intermediate media (obtained and recorded by other party).Data analysis technique by using Stuctural Equation Model (SEM), that is to test student perception of Sriwijaya University andSriwijaya State Polytechnic student toward professionalism of lecturer.

\section{THE RESULTS OF STATISTICAL TESTS}

Testing Data. Testing data is done to test the questionnaire that has been distributed to the selected sample will then be analyzed based on descriptive.

Test of Validity and Reliability. The validity test is done to see how far the indicators or statements in the questionnaire are really capable of measuring what you want to measure. So it can be said the higher the value of validity, then the statement is more precise about

Jurnal Manajemen/Volume XXIII, No. 03, October 2019: 427-443

DOI: http://dx.doi.org/10.24912/im.v23i3.579 
the targets. The determination of whether a statement in the questionnaire used in this study is valid, then the criterion used are the value of $t$-value in first order and the value of loading factor. If the value of $\mathrm{t}$-value in first order $>1,96$ and the value of factor loading $>$ 0,5 , then the statements are valid.

Reliability is the main character of a good measurement instrument. The main idea in the concept of reliability is the extent to which the measurement results are fixed, reliable and free from measurement error. Determination of whether a statement in the questionnaire used in reliable research, then the criteria used is to see the value of Construct Reliability $(\mathrm{CR})>=0,7$ and the value of Average Variace Extracted (AVE) $>=$ 0,5 .

The formulation of CR and AVE in Structural Equation Model (SEM) : (Gunarto, 2013)

$\mathrm{CR}$ and $\mathrm{AVE}=(\text { the sum of Loading Standardized })^{2}$

(the sum of Loading Standardized $)^{2}+($ the sum of Measurement Error)

Table 2. Validity and Realiability Test of Knowledge

\begin{tabular}{c|c|c|c|c}
\hline Variable & $\begin{array}{c}\text { Loading } \\
\text { Standardized }\end{array}$ & $\begin{array}{c}\text { (Loading } \\
\text { Standardized) }\end{array}$ & $\begin{array}{c}\text { Measurement } \\
\text { Error }\end{array}$ & \\
\hline K1 & 0,79 & 0,6241 & 0,3759 & Valid \\
\hline K2 & 0,77 & 0,5929 & 0,4071 & Valid \\
\hline K3 & 0,77 & 0,5929 & 0,4071 & Valid \\
\hline K4 & 0,71 & 0,5041 & 0,4959 & Valid \\
\hline K5 & 0,57 & 0,3249 & 0,6751 & Valid \\
\hline The Sum of & 3,61 & 2,6389 & 2,3611 & Valid \\
\hline & 13,0321 & & & \\
\hline CR & 0,84661409 & \multicolumn{2}{|l}{} & \\
\hline AVE & 0,52778 & Reliable & \\
\hline
\end{tabular}

Source: (Field data, 2017)

The value of Construct Reliability $(\mathrm{CR})>=0,7$ and the value of Average Variace Extracted $(\mathrm{AVE})>=0,5$. Meaning statements for each category are reliable.

The value of $\mathrm{t}$-value in first order greater than 1,96 and the value of factor loading greater than 0,5. Meaning statements in the questionnaire are valid.

Jurnal Manajemen/Volume XXIII, No. 03, October 2019: 427-443

DOI: http://dx.doi.org/10.24912/im.v23i3.579 
Table 3. Validity and Realiability Test of Skill

\begin{tabular}{|c|c|c|c|c|}
\hline Variable & $\begin{array}{r}\text { Loading } \\
\text { Standardized }\end{array}$ & $\begin{array}{r}\text { (Loading } \\
\text { Standardized) }\end{array}$ & $\begin{array}{l}\text { Measure } \\
\text { ment Error }\end{array}$ & \\
\hline S1 & 0,60 & 0,36 & 0,64 & Valid \\
\hline S2 & 0,59 & 0,3481 & 0,6519 & Valid \\
\hline S3 & 0,64 & 0,4096 & 0,5904 & Valid \\
\hline S4 & 0,53 & 0,2809 & 0,7191 & Valid \\
\hline S5 & 0,77 & 0,5929 & 0,4071 & Valid \\
\hline The Sum of & 3,13 & 1,9915 & 3,0085 & Valid \\
\hline & 9,7969 & & & \\
\hline $\mathrm{CR}$ & $\begin{array}{l}0,765060 \\
05\end{array}$ & & \multirow[b]{2}{*}{ Reliable } & \\
\hline AVE & 0,3983 & & & \\
\hline
\end{tabular}

Source: (Field data, 2017)

The value of Construct Reliability $(\mathrm{CR})>=0,7$ and the value of Average Variace Extracted $(\mathrm{AVE})>=0,5$. Meaning statements for each category are reliable.

The value of t-value in first order greater than 1,96 and the value of factor loading greater than 0,5. Meaning statements in the questionnaire are valid.

Table 4. Validity and Realiability Test of Personality

\begin{tabular}{c|c|c|c|c}
\hline Variable & $\begin{array}{c}\text { Loading } \\
\text { Standardized }\end{array}$ & $\begin{array}{c}\text { (Loading } \\
\text { Standardized) }\end{array}$ & $\begin{array}{c}\text { Measurement } \\
\text { Error }\end{array}$ & \\
\hline P1 & 0,72 & 0,5184 & 0,4816 & Valid \\
\hline P2 & 0,70 & 0,49 & 0,51 & Valid \\
\hline P3 & 0,74 & 0,5476 & 0,4524 & Valid \\
\hline P4 & 0,77 & 0,5929 & 0,4071 & Valid \\
\hline P5 & 0,73 & 0,5329 & 0,4671 & Valid \\
\hline The Sum of & 3,66 & 2,6818 & 2,3182 & Valid \\
\hline & 13,3956 & & & \\
\hline CR & 0,852473622 & \multicolumn{2}{|c}{ Reliable } & \\
\cline { 1 - 2 } AVE & 0,53636 & \multicolumn{2}{|l}{} \\
\hline
\end{tabular}

Source: (Field data, 2017)

The value of Construct Reliability $(\mathrm{CR})>=0,7$ and the value of Average Variace Extracted $(\mathrm{AVE})>=0,5$. Meaning statements for each category are reliable.

The value of t-value in first order greater than 1,96 and the value of factor loading greater than 0,5. Meaning statements in the questionnaire are valid. 


\section{DISCUSSION}

Description Analysis. Description analysis is done to see the distribution of data that has been done through distributing questionnaires to respondents. The form of questions asked is in the form of closed questions with answer categories using 5 likert scales, namely strongly disagree (sts), disagree (ts), neutral (n), agree (s), and strongly agree (ss)

Table 5. Students' Perceptions of Lecturers' Knowledge

\begin{tabular}{l|c|c|c|c|c|c|c|c|c|c|c|c}
\hline & \multicolumn{2}{|c|}{$(\mathbf{1})$} & \multicolumn{2}{c|}{$(\mathbf{2})$} & \multicolumn{2}{c|}{ (3) } & \multicolumn{3}{c|}{ (4) } & \multicolumn{3}{c}{ Mean } \\
\hline Attributes & I & II & I & II & I & II & I & II & I & II & I & II \\
\hline Knowledge 1 & 1 & 1 & 0 & 3 & 10 & 11 & 40 & 44 & 49 & 41 & 4,36 & 4,21 \\
\hline Knowledge 2 & 1 & 1 & 2 & 5 & 10 & 18 & 52 & 49 & 35 & 27 & 4,18 & 3,96 \\
\hline Knowledge 3 & 1 & 1 & 1 & 3 & 18 & 22 & 37 & 47 & 43 & 27 & 4,2 & 3,96 \\
\hline Knowledge 4 & 1 & 1 & 0 & 6 & 15 & 23 & 50 & 44 & 34 & 26 & 4,16 & 3,88 \\
\hline Knowledge 5 & 1 & 1 & 1 & 5 & 14 & 17 & 38 & 47 & 46 & 30 & 4,27 & 4 \\
\hline Total & 5 & 5 & 4 & 22 & 67 & 91 & 217 & 231 & 207 & 151 & & \\
\hline
\end{tabular}

Source: (Field Data, 2017), $(\mathrm{n}=200)$

Lecturers' knowledge was measured using a five-point Likert type scale in the quantitative data. Table 5 presented the findings based on students' degree of consent to items referring to lecturers' attributes/actions which are considered to be linked to the display of a lecturer knowledge in the Sriwijaya university (I) and Sriwijaya State Polytechnic (II). Respondents rated lecturers have the ability to explain the benefits of the courses given in helping to understand other subjects to solve practical problems beyond ability with the lowest mean score $(\mathrm{M}=4.16$ and $\mathrm{M}=3,88)$ among lecturers' knowledge.

However, a significant number of respondents perceived lecturers have the ability to master the material / content of lectures with the highest mean score $(\mathrm{M}=4,36$ and $\mathrm{m}=$ $4,21)$.

Table 6. Students' Perceptions of Lecturers' Skill

\begin{tabular}{l|l|l|l|l|l|l|l|l|l|l|l|l}
\hline & \multicolumn{2}{|c|}{ (1) } & \multicolumn{2}{c|}{$(\mathbf{2})$} & \multicolumn{2}{c|}{ (3) } & \multicolumn{2}{c|}{ (4) } & \multicolumn{2}{c|}{ (5) } & \multicolumn{2}{c}{ Mean } \\
\hline Attributes & I & II & I & II & I & II & I & II & I & II & I & II \\
\hline Skill 1 & 0 & 2 & 3 & 0 & 15 & 16 & 44 & 48 & 38 & 34 & 4,17 & 4,12 \\
\hline Skill 2 & 0 & 0 & 2 & 2 & 11 & 13 & 43 & 53 & 44 & 32 & 4,29 & 4,15 \\
\hline Skill 3 & 1 & 1 & 4 & 8 & 28 & 50 & 43 & 29 & 24 & 12 & 3,85 & 3,43 \\
\hline Skill 4 & 0 & 3 & 2 & 1 & 15 & 21 & 46 & 50 & 37 & 25 & 4,18 & 3,93 \\
\hline Skill 5 & 2 & 1 & 1 & 3 & 19 & 18 & 39 & 52 & 39 & 26 & 4,12 & 3,49 \\
\hline Total & 3 & 7 & 12 & 14 & 88 & 118 & 215 & 232 & 182 & 129 & & \\
\hline
\end{tabular}

Source: (Field Data, 2017), $(\mathrm{n}=200)$

The second research objective for this study sought to examine how students viewed their lecturers' skill in Sriwijaya Uniersity (I) and Sriwijaya State Polytechnic (II). From 
the results presented in Table 6, respondents rated lecturers have communication skills in a foreign language ( $M=3,85$ and $M=3,43)$ as the lowest among the items considered.

The data, revealed that respondents perceived lecturers have expertise in the field of science in explaining the course material $(M=4,29$ and $M=4,15)$.

Table 7. Students' Perceptions of Lecturers' Personality

\begin{tabular}{l|c|c|c|c|c|c|c|c|c|c|c|c}
\hline & \multicolumn{2}{|c|}{$(\mathbf{1})$} & \multicolumn{2}{c|}{ (2) } & \multicolumn{2}{c|}{ (3) } & \multicolumn{2}{c|}{ (4) } & \multicolumn{3}{c|}{ (5) } & \multicolumn{2}{c}{ Mean } \\
\hline Attributes & I & II & I & II & I & II & I & II & I & II & I & II \\
\hline Personality 1 & 1 & 3 & 3 & 9 & 30 & 24 & 43 & 39 & 23 & 25 & 34,8 & 3,74 \\
\hline Personality 2 & 2 & 2 & 4 & 10 & 31 & 25 & 40 & 39 & 23 & 24 & 3,78 & 3,73 \\
\hline Personality 3 & 1 & 0 & 1 & 1 & 18 & 23 & 34 & 38 & 46 & 38 & 4,23 & 4,13 \\
\hline Personality 4 & 1 & 1 & 4 & 9 & 24 & 29 & 38 & 40 & 33 & 21 & 3,98 & 3,71 \\
\hline Personality 5 & 0 & 1 & 4 & 3 & 19 & 32 & 35 & 40 & 42 & 24 & 4,15 & 3,83 \\
\hline Total & 5 & 7 & 16 & 32 & 122 & 133 & 190 & 196 & 167 & 132 & & \\
\hline
\end{tabular}

Source: (Field Data, 2017), $(\mathrm{n}=200)$

Five constructs were used to measure how students view their lecturers' personality in the Sriwijaya University (I) and Sriwijayan State Polytechnic (II). According to the results in Table 7, the respondents rated lecturers have good appearance and behavior $(\mathrm{M}=$ 4,23 and $\mathrm{M}=4,13$ )as the highest among the items considered.

The results, however, indicated that the respondents ratedlecturers have openness and honesty towards students in all things in the teaching and learning process $(\mathrm{M}=3,78)$ andlecturers have objectivity in evaluating student achievement learning outcomes $(\mathrm{M}=$ 3,71 ) as the lowest among the items considered.

Model Testing and Inference Analysis. The model used in the study refers to the model proposed by Linjee and Homkaew. Professionalism of lecturers is measured by three indicators, namely lecturer knowledge, lecturer skill, and lecturer personality. Students as a sample are asked for their perception of the professionalism of the lecturer. Students are distinguished in two Higher Education environments, namely Sriwijaya State Polytechnic, as Vocational Education and University of Sriwijaya, as the organizer of Academic Education. Model testing is conducted to see student perception in the two environments of the College. The test instrument is using the Structural Equation Model (SEM) with Linear Structural Relations (LISREL). 
Khairunnisa, Ariyanti, Novita and Ganiardi: Student Analysis Of Differences ...

Figure 2. Standardized Solution Construck of Knowledge, Skill and Personality

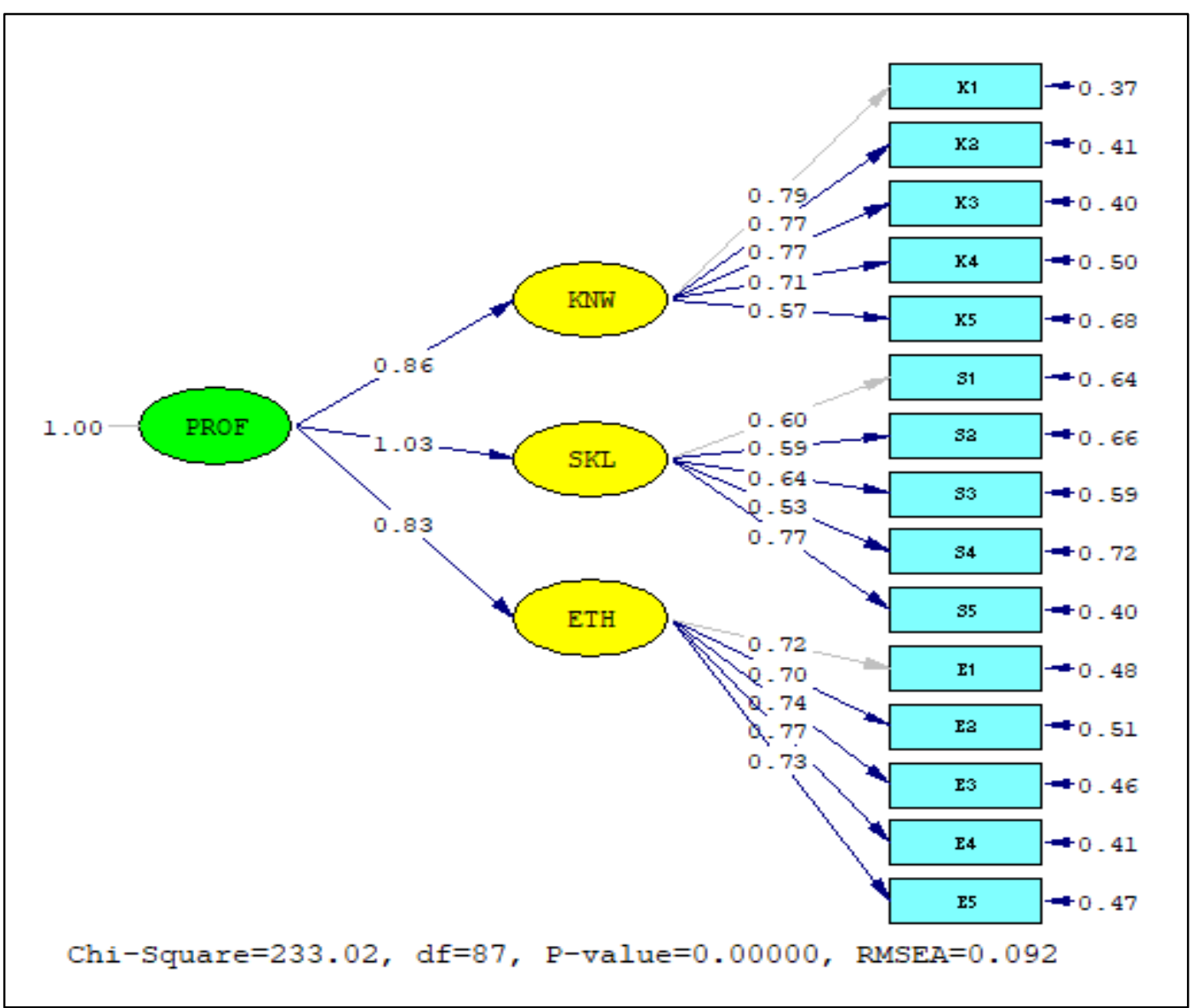

Source: (Field Data, 2017) 
Figure 3. T-value Construct of Knowledge, Skill and Personality

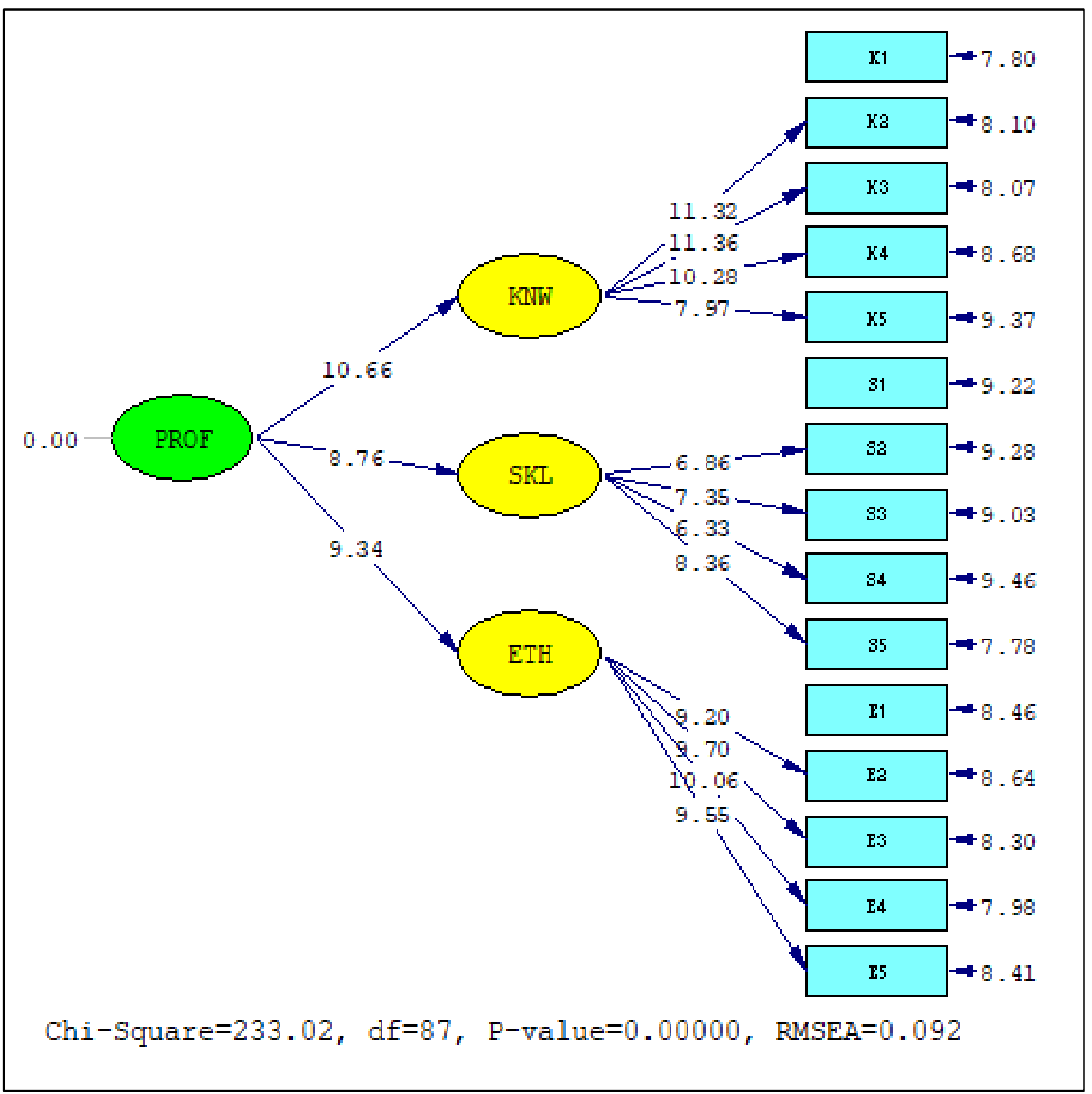

Source: (Field Data, 2017)

The result of model test by using SEM with LISREL got result that lecturer professionalism factor from knowledge side significantly, as seen from $t$ test value equal to 10,66 . The value for lecturer professionalism factor in skills side also significantly, where the $t$ test is 8,76 . The lecture professionalism factor from personality side, $t$ test is 9,34 . There is significantly, when the value of $t$ test $>t$ table $(1,96)$. There is a positive relationship between knowledge, skills, and personality toward an lecture professionalism. The value of positive relationship between knowledge and professionalism is 0,86 . The value of positive relationship between skill and professionalism is 1,03. And the value of positive relationship between personality and professionalism is 0,83 .

The professionalism of lecturers in terms of lecturer knowledge and lecturer skill between vocational education and academic education is significantly different, while

Jurnal Manajemen/Volume XXIII, No. 03, October 2019: 427-443 DOI: http://dx.doi.org/10.24912/im.v23i3.579 
lecturer professionalism in terms of personality between vocational education and academic education is the same. Lecturer's personality have an influence on student ratings of teaching quality, even when students have been awarded to the irrelevance of personality characteristics in evaluating teaching (Mkhdramine and Essafi, 2016). According to student lecturer personality is not the main thing in the learning process, the most important is the knowledge and skills of lecturers should be adjusted to the educational background of lecturers. Because between vocational education and academic education has different educational goals, where the vocation is more emphasis on skills while the academic emphasis is more on knowledge. Based on the list of questions asked, in terms of knowledge, lecturers should have the ability to master the material / content of the lecture, have the ability to make quality questions in the task or exam, have the quality of teaching materials / lecture modules, have the ability to explain the benefits of the eye lectures given, and have the ability of knowledge appropriate educational background. While in terms of skills, lecturers should have the ability in using the tools supporting the teaching and learning process, having the expertise in the field of science in explaining the lecture materials, having the ability to communicate in foreign languageshas the ability to make lecture material planning that will be submitted, and has the ability to solve problems / cases in accordance with lecture materials. Research conducted by Nurchayati(2012) about the influence of knowledge, skill and character of lecturer to student's GPA that there is no influence between the character of accounting lecturer to student's GPA. This is because the character is the personal nature of the lecturer so it is not related to the teaching and learning process. Characters are described as human nature in general where human beings have many properties that depend on their own life factor. Character is the personality of the lecturer. Based on the list of questions asked, the lecturer should have attention to student achievement ability, have openness / honesty, have good appearance / behavior, have objectivity in the assessment of learning outcomes and have attitude to grow student thinking critical / creative. According to (Linjeeand Homkaew, 2016), an accountant can be said to be professional if it has the knowledge, skills, values, ethics and professional attitude. There is a positive relationship between knowledge, skills, values, ethics, and professional attitudes toward an accountant's performance.To be effective, lecturers need a combination of professional knowledge and specialized skills as well as their own personal qualities and experiences. Moreover, acquiring new skills and adding to their knowledge are among the major reasons lecturers endeavor to attend activities designed for professional development (Alibakhshi and Dehvari, 2015).Mensah and Charles (2016) said that students held positive perceptions on the teaching performance of lecturers in the following attributes: knowledge of subject matter, use good examples, stick to the syllabus, examinations closely related to covered areas, respect for and interest in students, and reprimand recalcitrant students in case of negative behaviour

Jurnal Manajemen/Volume XXIII, No. 03, October 2019: 427-443

DOI: http://dx.doi.org/10.24912/im.v23i3.579 


\section{CONCLUSION}

The conclusion of this research result, there is a positive relationship between knowledge, skills, and personality toward an lecture professionalism. The student perception toward professionalism of lecturer seen from different knowledge and skill factor between vocational education with academic education, while from personality factor is same. Lecturer knowledge and lecturer skills are the determining factor in the success of the teaching and learning process, while the lecturer personality is a supporting factor.

Suggestions for further research is to conduct research for other universities outside the Sriwijaya State Polytechnic and Sriwijaya University. Factors in assessing lecturer professionalism can be added in addition to knowledge, skills, and personality.

\section{REFERENCES}

Agustin, Risa. (2018).Kamus Lengkap Bahasa Indonesia. Surabaya : Serba Jaya.

Alibakhshi, Goudarz and Najibah Dehvari. (2015). EFL Teachers' Perception of Continuing Professional Development : A Case of Iranian High School Teachers. Profile. Vol.17 No.2. July-December. Page.29-42.

Creasy, Kim L. (2015). "Defining Professionalism in Teacher Education Program". Journal of Education of Social Policy. Vol.2 No.2. June. Page.23-25.

Gunarto, Muji. (2013).Membangun Model Persamaan Struktural (SEM) dengan Program Lisrel.Palembang : Tunas Gemilang Press.

Hidayati, Frieda N R and Siswati. (2017). 'Correlation Between Lecturer Professionalism and Self_Efficacy in College Students'. International Research-Based Education Journal. Vol.1 No.2. July. Page.115-121.

Kemenkeu. (2005).Undang-undang Republik Indonesia Nomor 4 Tahun 2005 (Retrieved fromhttps://jdih.kemenkeu.go.id/fullText/2005/14TAHUN2005UU.htm/6-8-2015).

Komba, Willy L M, William A L Anangise and Joviter K Katabaro. (2013). "The Development of Teacher Professional Identity at University of Dar es Salaam : Perceptions and Influencing Factors'. Journal of International Cooperation in Education. Vol.15 No.3. Page.187-204.

Kotler, Philip. (2018). Manajemen Pemasaran. Edisi Bahasa Indonesia. Cetakan Ketiga.Jakarta : Indeks.

Linjee, Chalida. And Kanokmani Homkaew. (2016). "The Relationships Between Knowledge, Skill, Value, Ethics, and Attitudes on Competences of Certified Public Accountants in Thailand". International Journal of The Computer. The Internet, and Management. Vol.24 No.3 Septenber-December. Page.49-53.

Marmah, Alex Amertei. (2014). "Students'Perception about the Lecture as Method of Teaching in Tertiary Institution, View of Student from College of Technology Education". International Journal of Education and Research. Vol.2 No.6 June. Page.601-612.

Mensah, Dominic Kwaku Danso and Asamoa Boateng Charles. (2016). "The Perceptions and Attitudes of Students Toward Lecturers at A Ghanaian Public University'.

Jurnal Manajemen/Volume XXIII, No. 03, October 2019: 427-443

DOI: http://dx.doi.org/10.24912/im.v23i3.579 
International Journal of Interdisiciplinary Research Methods. Vol.3 No.1. March.Page.1-9.

Miller, Cynthia J and Michael J Metz (2014). A Comparison of Professional Level Faculty and Student Perception of Active Learning : Its Current Use Effectiveness and Barriers. Advance Physiol Education. No.38. Page.240-252.

Mkhdramine, Said and Khadija Essafi. (2016). First Year Student Perceptions of Teacher and Teaching Effectiveness A New Approach in the Evaluation of Educational. Journal of Research and Methods in Education. Vol.6 Isuue.6. NovemberDecember. Page.55-62.

Mofreh, Samah Ali Mohsen, M Najib Ghafar and Abdul Hafiz Hj Omar. (2013). A Study of Lecturers' Perceptions on Teaching Functions Among the Lecturers of Community College, Yemen. International Journal of Scientific and Technology Research. Vol.2 Issue 12. December. Page.109-112.

Nurchayati. (2012). "Persepsi Mahasiswa Terhadap Profesionalisme Dosen Akuntansi Fakultas Ekonomi Universitas 17 Agustus Semarang". Serat Acitya. Hal 1-11.

Pamukkale. (2012). "Teacher Candidates' Attitude Toward The Teaching Professions in Turkey'. Alberta Journal of Educational Research. Vol.58 No.3 Fall. Page.381-403.

Priyatno, Duwi. (2014). SPSS 22 Pengolah Data Terpraktis. Yogyakarta : Andi.

Rahman, Ali Wira. (2017). "Student Perception Toward Good Lecturer Pendagogical Competence".(Retrieved fromhttp://www.researchquate.net/publication/324674976). March.

Ramadhan, Arwan Nur dan Soenarto. (2015). "Pengaruh Persepsi Siswa Terhadap Faktorfaktor yang Mempengaruhi Prestasi Belajar Teori Kejuruan Siswa SMK'. Jurnal Pendidikan Vokasi. Vol.5 No.3 November. Hal.297-312.

Ristekdikti. (2003).Undang-undang Republik Indonesia Nomor 20 Tahun 2003 (Retrieved fromhttps://kelembagaan.ristekdikti.go.id/wpcontent/uploads/2016/08/UU_no_20_th_2003.pdf/6-8-2015).

Subagyo, P. Joko. (2004). Metode Penelitian: Dalam Teori dan Praktek. Jakarta: Renika Cipta.

Sugiyono. (2018). Metode Penelitian Kuantitatif. Bandung: CV Alfabeta.

Supomo, B dan N. Indriantoro. (2002). Metodologi Penelitian Bisnis Untuk Akuntansi dan Manajemen. Yogyakarta: BPFE.

Susanto, Ratnawati. (2018). Analysis of Lecturers'Professionality Toward Pre-Service Teachers'Professional Commitment (Capacity Building of Teacher Training and Education Faculty)'. Jurnal Indira. Vol.3 No.3 November. Page. 249-262.

Susanto, Ratnawati (2019). Lecturers' Professionalism in Shaping Students' Perceptions and Commitments. Journal of Educational and Evaluation. Vol.3 No.1 page.25-38.

Tim Penyusun Kamus Pusat Pembinaan dan Pengembangan Bahasa. (1996). Kamus BesarBahasa Indonesia. Jakarta : Balai Pustaka.

Umar, Husein. (1999). Metodologi Penelitian Aplikasi dalam Pemasaran. Jakarta: PT Gramedia Pustaka Utama.

Wardoyo, Cipto, Aulia Herdiani and Sulikah. (2017). Teacher Professionalism : Analysis of Professionalism Phases. International Education Studies. Vol.10. No.4. Page.90100.

Wibowo. (2014).Perilaku Dalam Organisasi. Jakarta : Raja Grafindo.

Jurnal Manajemen/Volume XXIII, No. 03, October 2019: 427-443

DOI: http://dx.doi.org/10.24912/jm.v23i3.579 
Zakiyah, Siti dan Desi Nurwidawati. (2017). "Pengaruh Persepsi Mahasiswa Tentang Cara Mengajar Dosen Terhadap Perilaku Asertif Mahasiswa Psikologi di Universitas Negeri Surabaya”. Jurnal Psikologi Pendidikan. Vol.14 No.3 Hal.1-7. 